\title{
Diagnostic Approach in Isolated Bulbar Amyotrophic Lateral Sclerosis: A Case Report
}

\section{Nunung Nugroho', Albert Setiawan ${ }^{2}$}

${ }^{1}$ Department of Physical Medicine and Rehabilitation, Faculty of Medicine, Widya Mandala Catholic University, Primasatya Husada Citra Hospital ,Surabaya, Indonesia

${ }^{2}$ Department of Physical Medicine and Rehabilitation, Faculty of Medicine, Widya Mandala Catholic University, Surabaya, Indonesia

\begin{abstract}
Introduction: Amyotrophic lateral sclerosis (ALS) is the most common motor neuron disease. Based on the clinical manifestation, it is divided into spinal form and bulbar form. Bulbar form ALS is divided into two, progressive bulbar and isolated bulbar ALS (IBALS). Patients are diagnosed with IBALS when symptoms are isolated in the bulbar region for at least six months. The prevalence of IBALS represents only $4 \%$ of the neuron disease.
\end{abstract}

Objective: To provide the diagnostic approach of IBALS case based on the clinical signs and symptoms, physical examination, laboratory and radiology findings, electromyography, and fiber optic laryngoscopy examination.

Case: A 64-year-old woman presented with slurred speech, the symptoms appeared 2 years ago. Within the last 6 months, the symptoms deteriorated, the patient was unable to speak, and had major difficulty in swallowing food and drinks. The functional status impairment was limited in the bulbar region. Laboratory and radiology findings did not lead to any certain disease. Electromyography and fiber optic laryngoscopy results suggesting a motor neuron disease.

Conclusion: It is important to diagnose ALS patients to determine the treatment, progressivity, and prognosis of the disease.

Keywords: amyotrophic lateral sclerosis, bulbar form, diagnosis 


\section{ABSTRAK}

Latar Belakang: Sklerosis lateral amiotrofik (SLA) merupakan penyakit motor neuron yang tersering. Berdasarkan manifestasi klinisnya dibagi menjadi 2, bentuk spinal dan bulbar. SLA bentuk bulbar dibagi menjadi dua, SLA bulbar progresif dan terisolasi. Pasien didiagnosis dengan SLA bulbar terisolasi apabila gejala terbatas pada regio bulbar setidaknya selama 6 bulan. Prevalensi dari SLA bulbar terisolasi mewakili hanya $4 \%$ dari penyakit penyakit motor neuron.

Tujuan: Untuk menyediakan pendekatan diagnosis dari kasus sklerosis lateral amiotrofik bulbar terisolasi berdasarkan keluhan dan gejala, pemeriksaan fisik, hasil pemeriksaan laboratorium dan radiologis, dan hasil elektromiografi dan laringoskopi fiber optik.

Kasus: Seorang wanita 64 tahun datang dengan keluhan kesulitan dalam berbicara, keluhan timbul sejak 2 tahun yang lalu. Keluhan memburuk sejak 6 bulan terakhir, pasien tidak dapat berbicara, dan mengalami kesulitan dalam menelan makanan dan minuman. Air liur pasien tidak dapat dikontrol dan selalu menetes saat pasien makan dan minum. Kemampuan fungsional pasien yang terganggu hanya pada regio bulbar. Dari hasil pemeriksaan laboratorium dan radiologis tidak ditemukan hasil yang bermakna untuk mengarahkan ke sebuah diagnosis. Hasil elektromiografi dan laringoskopi fiber optik mengarahkan ke suatu penyakit motor neuron.

Kesimpulan: Mendiagnosis pasien ALS merupakan hal penting untuk menentukan tata laksana, progresivitas dan prognosis dari penyakit.

Kata Kunci: bentuk bulbar, diagnosis, sklerosis lateral amiotrofik

\section{INTRODUCTION}

\section{Correspondent Detail:}

\section{Nunung Nugroho}

Department of Physical Medicine and Rehabilitation, Faculty of Medicine, Widya Mandala Catholic University. Primasatya Husada Citra Hospital, Surabaya. Fax: +6231-99005277.

Phone number: +62811340264

Email: nunung@ukwms.ac.id.
Amyotrophic lateral sclerosis (ALS) also known as motor neuron disease, it is a progressive neurogenerative disease which affects the upper and lower motor neuron leading to muscle weakness and atrophy. ${ }^{1,2}$

ALS is categorized based on the familial history and the clinical manifestation that appears on the patient. Patients with a family history of ALS are categorized as familial ALS (fALS), for patients with no familial history is categorized as sporadic (sALS). ${ }^{1}$ Based on the clinical manifestation it is divided into spinal form or limb-onset which involves the trunk 
and limb, and bulbar form or bulbar-onset which involves the patient's ability to speak and swallow. ${ }^{1,3}$

ALS is the most common motor neuron disease in adults, it represents $85 \%$ of all motor neuron disease cases. ${ }^{4}$ The incidence of ALS is at 0.6 and 3.8 per 100,000 person-years. ${ }^{5}$ The incidence rate in men are twice more often than women. It may affect any stage of age, but it mostly appeared between 54 to 69 years old. ${ }^{5,6} 70 \%$ of patients with ALS appeared with spinal onset, and $30 \%$ of patients appeared with bulbar onset. ${ }^{6}$ The bulbar onset is divided into two types, progressive bulbar palsy (PBP) and isolated bulbar palsy (IBP) or isolated bulbar amyotrophic lateral sclerosis (IBALS). ${ }^{7,8}$ Patients with insidious onset of palsy isolated to the bulbar region for at least six months, spastic or flaccid dysarthria, preserved respiratory and sensory functions, and are diagnosed with IBALS. ${ }^{8}$ Patients with IBALS represent only $4 \%$ of patients with motor neuron disease, more often found in women, and with an older onset of age. As the progression is slower, patients have a better prognosis. ${ }^{7,8}$ Here we report the diagnostic approach in a patient with isolated bulbar amyotrophic lateral sclerosis.

\section{CASE DESCRIPTION}

A 64-year-old woman was referred from ear nose and throat clinic on September 1 ${ }^{\text {st }}, 2020$. with the chief complaint of slurred speech, the patient was accompanied by her daughter. Information was obtained from hetero anamnesis, the patient's symptoms appeared two years ago. Symptoms deteriorated within the last six months, the patient was unable to speak and had major difficulty in swallowing food and drinks. The patient's saliva drooling every time she eats and it takes a long period to finish her meal.

Before the onset of illness, her weight was 50 $\mathrm{kg}$, it went down to $41 \mathrm{~kg}$ within a year and the patient felt a decrease in her muscle mass. There was no family member with similar signs and symptoms as the patient, and the patient has no history of hypertension, diabetes mellitus, and other metabolic diseases. The patient's independence in doing her activities of daily living was measured by using the modified Barthel index. The result showed that the patient did her activity of daily living independently, and she was also able to do her job as a grocery seller. To maintain her functional status when the hoarseness symptom appeared, she used an electronic device to type and to communicate with her family and buyers.

Radiology and laboratory examination had been done in the past two years ago when the symptoms appeared to investigate the diagnosis. The patient had undergone head magnetic resonance imaging (MRI) on October $22^{\text {nd }}, 2018$. The result showed small vessels ischemic on the right subcortical frontal lobe and left corona radiata, no acute infarction was found, and other structures of the brain were within normal limits. Magnetic resonance angiography showed there was no significant stenosis of intracranial major artery, aneurysm or vascular malformation. The laboratory result of complete blood count, blood glucose, liver, and kidney function tests were within normal limits. There was an increase in total cholesterol (267 mg/dL) and low-density lipoprotein (LDL) level (198 mg/dL). 
On February $28^{\text {th }}$ ，2019, an electromyography (EMG) examination was done, result showed severe bilateral carpal tunnel syndrome, myasthenia gravis bulbar type but motor neuron disease still could not be excluded, nerve root irritation in the bilateral fifth level of lumbar, and first-level sacral vertebrae. The patient was prescribed Pyridostigmine bromide twice a day. After five months of taking the medicine, the symptoms didn't subside. For further investigation, a head CT-scan without contrast was done on November $27^{\text {th }}, 2019$. The results showed a sub-acute cerebral infarction in the left external capsule of the brain. She underwent rehabilitation treatment to treat her difficulties in speaking, but the symptoms remained. The patient went to our hospital for further evaluation and treatment.

A recent physical examination was done on September $5^{\text {th }}, 2020$, in the Physical Medicine

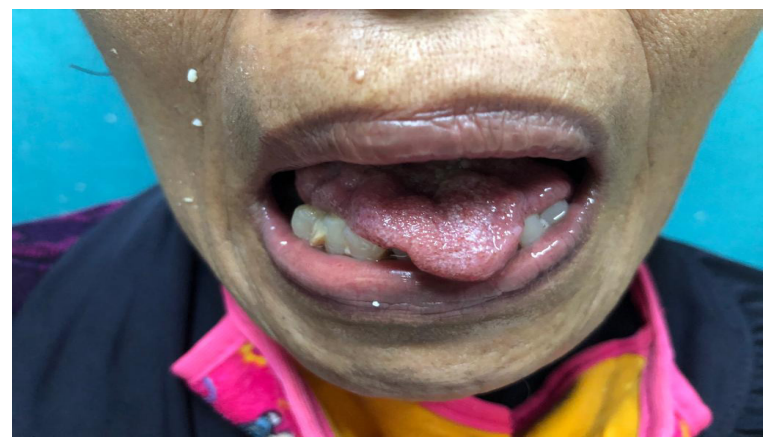

Figure 1. Lingual atrophy and Rehabilitation clinic. The patient's Glasgow coma scale was $4 \times 6$, her verbal response was not assessable because the patient had hoarseness Vital signs were within normal limits, no cyanosis and dyspnea were found on the patient. Her height and weight were 142 $\mathrm{cm}$ to $41 \mathrm{~kg}$, with a body mass index (BMI) of $20.33 \mathrm{~kg} / \mathrm{m}^{2}$. Head and neck inspection showed the patient was drooling, there was a decline in masseter muscle tone. The patient could not smile, close her mouth tightly, and purse her lips. Hypoglossal examination it was found that she was unable to protrude and move her tongue, lingual atrophy (Figure 1), and fasciculation was found. Through general inspection, atrophies were found on her masseter muscles, upper trapezius muscles (Figure 2), hypothenar, thenar (Figure 3), and almost in all other muscles of upper and lower extremities.

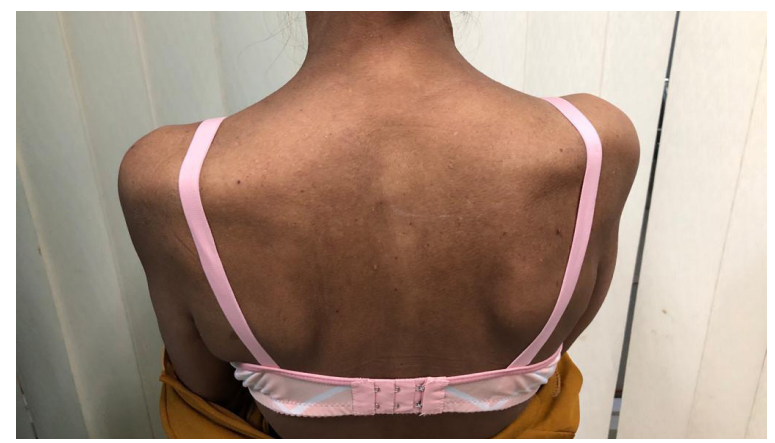

Figure 2. Atrophy of trapezius and other back muscles.

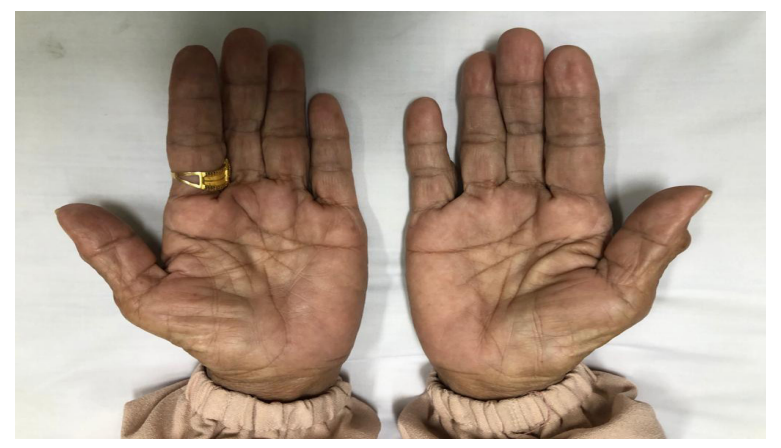

Figure 3. Atrophy of thenar and hypothenar muscle 
Neurological examination was done, the sensory function of both median nerve and motor test of thumb adduction and opposition of thumb was impaired with the manual muscle test result of grade 4, while other parts and extremities of the sensory and motor test were within normal limits. Brisk tendon reflexes of Achilles, knee, biceps were found and pathological reflexes of Hoffman, Tromner reflex were positive at both sides and jaw jerk reflex was also positive. Muscle clonus was found on the left ankle, and carpal tunnel tests were found positive on both sides. Diagnostic tests of laboratory and electromyography were done to find out the diagnosis. The laboratory tests of complete blood count, liver and kidney function, blood glucose level, serum electrolyte levels were all within normal limits. There was an increase in the total cholesterol $(272 \mathrm{mg} / \mathrm{dL})$ and LDL level $(202 \mathrm{mg} / \mathrm{dL})$. The first EMG result on February $28^{\text {th }}, 2019$, result showed severe bilateral carpal tunnel syndrome, myasthenia Gravis bulbar type but motor motor neuron disease still could not be excluded, nerve root irritation in the bilateral fifth level of lumbar, and first-level sacral vertebrae. The second electromyography test was done on August $28^{\text {th }}, 2020$, to reevaluate the patient's condition and to find out the disease. The result showed severe bilateral carpal tunnel syndrome and there was nerve denervation on the glossopharyngeal and hypoglossal nerve, lumbar, and cervical nerve region suggesting a motor neuron disease. Fiber optic laryngoscopy examination was done to evaluate the patient's vocal cord (Figure 4), the result showed no obstruction or limitation during the inspiration phase, atrophy of left vocal cord was found, and during the phonation phase the vocal cord adducted not in the middle, results support the diagnosis of ALS.

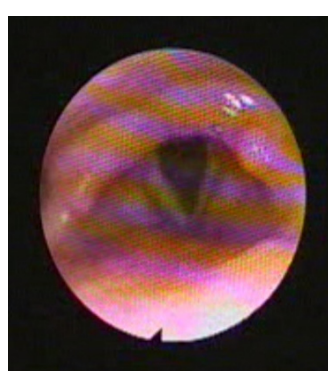

(a)

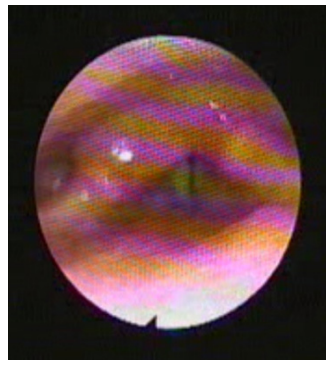

(b)

Figure 4. Fiber optic laryngoscopy examination; (a) during the inspiration phase, (b) during phonation phase.

After undergoing a series of physical examination, radiology, and laboratory tests, the results didn't lead to a certain disease that explains the clinical signs and the progressivity of the symptoms that excluded the differential diagnosis of the patient's symptoms. The electromyography and fiber optic laryngoscopy examination results support the diagnosis of isolated bulbar amyotrophic lateral sclerosis.

The patient's functional status was evaluated using the ALS Functional Rating Scale- 
Revised (ALSFRS-R). An instrument consists of 12 items evaluating the bulbar, fine motor, gross motor, and respiratory function. Using the ALSFRS-R, the patient scored 40 out of 48 . The bulbar functions were majorly affected, the patient only scored 1 out of 4 for both speech and salivation criteria. The patient combined speech and non-vocal communication, and she got excess of saliva with some drooling. In swallowing criteria, she scored 2 out of 4 as the dietary consistency was changed to less solid food to enable the patient to crush and swallow the food.

Treatments were given to the patient to slow down the progress of the disease, to maintain the patient's functional function, and to help to optimize the bulbar function. Oral motor exercises, indirect and direct feeding were also given to the patient to treat speech, salivation, and swallowing problems.

The food consistency and amount were adjusted according to the patient's ability to improve oral swallowing ability. To maintain the patient's motoric function, the patient was given therapeutic exercises to improve the muscle strength exercise and stability to maintain mobility and maintain the functional status in doing her activity of daily living. Pharmacological treatment of Riluzole $50 \mathrm{mg}$ was given twice a day $\&$ neurotropic vitamins trice a day to slow down the progression of symptoms.

\section{DISCUSSION}

In this case, a 64-year-old woman was diagnosed with IBALS. This disease was found three times more often in women than in men. The onset age was older than the classic bulbar ALS, a study found that the of this disease mean age is $58.5 \pm 8.2$ years. $^{7}$

During the first two years, symptoms were confined on the bulbar region causing difficulties in speech and swallowing function, but limb and respiratory function were preserved. ${ }^{1}$ Symptom deteriorated and progressed to extremities causing muscle atrophy in several regions, but the patient's functional status was maintained as activities of daily living were still done independently. The activity of daily living dependency was measured using the modified Barthel index instrument, the result showed that the patient was independent with a total score of $20 .{ }^{9}$ Progression of symptoms in IBALS were slower compared to progressive bulbar ALS, this leads to a longer survival period. The median survival period of isolated bulbar compared to the progressive bulbar is 14 months longer. ${ }^{6,7}$

Recent physical examination revealed upper and lower motor neuron dysfunctions in the bulbar and other regions. Sensory dysfunction was limited only on both median nerves, and respiratory function was still preserved. To exclude the differential diagnosis, several workup tests were done, radiology and laboratory results did not lead to any specific diagnosis. Electromyography was done to do re-evaluate the patient's condition, result showed nerve denervation in several regions leading to a motor neuron disease (Table 1). 
Table 1. Amyotrophic lateral sclerosis electrodiagnostic criteria (WFN revised El Escorial) ${ }^{10}$

Criteria

Patient's EMG Result August $28^{\text {th }} 2020$

\section{A. Nerve conduction examination}

Normal nerve conduction or close to normal, sensory nerve conduction may be abnormal if entrapment syndrome and peripheral nerve disease appeared at the same time.

\section{B. Electromyography needle examination}

Combination of active and chronic denervation. Active denervation: fibrillation and positive sharp wave

Chronic denervation: Large MUAP (increased duration, amplitude, and polyphasic), decreased interference pattern,

Firing rate more than $10 \mathrm{~Hz}$

Unstable MUAP

\section{Chronic denervation and reinnervation}

On the brainstem region: changes at least in one muscle (lingual, facial, or masseter muscle)

Vertebra thoracal region: change in paraspinal muscle, on level T6 or below, or abdominal muscles

Cervical or lumbosacral region (at least 2 muscles innervated by different radix or peripheral nerve)
Right and left medianus nerve was impaired (carpal tunnel syndrome)

Left tibialis anterior, right and left trapezius, left flexor carpi radialis, and right hyoglossus.

- Increased duration on left tibialis anterior

- Increased amplitude (giant potential) hasn't appeared

- Polyphasic on left tibialis anterior and right trapezius $(2+)$, and left trapezius $(1+)$

- Decreased interference pattern on the left tibialis anterior, right and left trapezius, left flexor carpi radialis, right gastrocnemius, and right hyoglossus.

Not found

Not found

Hyoglossus lesion

Not found (still within normal limits)

Recruitment and decreased interference pattern on:

- $\mathrm{C} 3-4$

- $\mathrm{C} 6-7$

- L4-5

- $\mathrm{S} 1-2$
The diagnosis of isolated bulbar amyotrophic lateral sclerosis (IBALS) was made based on the progressive neurologic symptoms, Elescorial criteria of upper and lower motor neuron dysfunction findings in 3 regions, diagnostic test results that lead to no significant diagnosis, and the electromyography test which leads to a motor neuron disease..$^{3,7,8,11}$
The fiber optic laryngoscopy test showed there was a paralysis especially during the phonation phase causing the vocal cord not to adduct in the middle, amyotrophic lateral sclerosis is one of the neurological causes of vocal cord paralysis. ${ }^{12}$ Until now, there is no cure for ALS. Rehabilitation plays an important role to maintain the patient's functional status, the 
patient is given exercises to maintain speech, salivation, and swallowing functions so the patient can still be independent, manage the symptoms appeared, and helping the patient to have a great quality of life in patients' last years. $^{13}$

Pharmacological treatment of ALS can be given to slow down the disease progression, Riluzole $50 \mathrm{mg}$ with a dose recommendation of twice a day was given to the patient. Riluzole is a drug with glutaminergic antagonist activity, it is the only licensed drug for ALS patients. A meta-analysis study showed that Riluzole can extend 2-3 months of survival in ALS patients, it increases up to $9 \%$ chance to add 1 additional year to ALS patients. ${ }^{14,15}$ Evaluation of patients with ALS bulbar-onset were done by using the ALSFRS-R score, this instrument helps to evaluate the functional status. It is one of the instruments that is recommended as it meets the basic measurement requirements for ALS patients. ${ }^{16}$ The patient will be monitored using this instrument to find a further progression of the disease

\section{CONCLUSIONS}

Diagnosing amyotrophic lateral sclerosis (ALS) needs a comprehensive and thorough examination to exclude the differential diagnosis. Even the cure to ALS still has not been found until now, diagnosing and specifying the type of ALS is important to determine the treatment and to educate the patient about the disease. In this case, the diagnosis was made from the clinical signs and symptoms, physical examination, radiology and laboratory findings, electromyography, and fiber optic laryngoscopy examination. Treatments were given to enhance the patient's quality of life by slowing down the disease progression, maintaining the optimal functional status, and preventing further complications that may appear. The disease progression and prognosis of amyotrophic lateral sclerosis disease should be well understood by the patient and the family members to provide environmental support for the patient in fighting this disease. Further evaluation will be needed to monitor the progression of the patient's disease.

\section{REFERENCE}

1. Portaro S, Brizzi T, Naro A, Conti Nibali V, Morabito R, Bramanti A, et al. Acute onset of bulbar amyotrophic lateral sclerosis after flu - look at the differential diagnosis: A case report. J Int Med Res 2018; 46(7): 2933-7

2. Subaida FK, Sarju D, Abdulkhadar BM, Venugopal D. Amyotrophic Lateral Sclerosis (ALS) - A Case Report. Indian J Pharm Pract 2017; 10(2): 151-2.

3. Jamrozik Z, Gawel M, Szacka K, Bakon L. A Case Report of Amyotrophic Lateral Sclerosis in a Patient With KlippelFeil Syndrome - a Familial Occurrence. Medicine (Baltimore) 2015; 94(4): e441.

4. Qazi A, Malik F, Shafi L, Basar S, Qazi A. Young-onset Amyotrophic Lateral Sclerosis with Rare Skin Manifestation: Case Report and Literature Review. Cureus 2020; 12(4).

5. Longinetti E, Fang F. Epidemiology of amyotrophic lateral sclerosis. Curr Opin Neurol 2019; 32(5): 771-6. 
6. Mehta PR, Jones AR, Opie-Martin S, Shatunov A, Iacoangeli A, Al Khleifat A, et al. Younger age of onset in familial amyotrophic lateral sclerosis is a result of pathogenic gene variants, rather than ascertainment bias. J Neurol Neurosurg Psychiatry 2019; 90(3): 268-71.

7. Zhang H-G, Chen L, Tang L, Zhang N, Fan D-S. Clinical Features of Isolated Bulbar Palsy of Amyotrophic Lateral Sclerosis in Chinese Population. Chin Med J (Engl) 2017; 130(15): 1768-72.

8. Jawdat O, Statland JM, Barohn RJ, Katz JS, Dimachkie MM. Amyotrophic Lateral Sclerosis Regional Variants (Brachial Amyotrophic Diplegia, Leg Amyotrophic Diplegia, and Isolated Bulbar Amyotrophic Lateral Sclerosis). Neurol Clin 2015; 33(4): 775-85.

9. Ministry of Health of the Republic of Indonesia. Instrumen Pengkajian Paripurna Pasien Geriatri (P3G). 2017; 1.

10. Poernomo H, Basuki M WD. Motor Neuron Disease. In: Petunjuk Praktis Elektrodiagnostik. Surabaya: Airlangga University Press; 2003. p. 205-8.
11. Moirangthem V, Ouseph MM. Atypical Presentations of Amyotrophic Lateral Sclerosis: A Case Report. J Neuro Clin Neurosci 2011; 23(3): 362-4.

12. House SA, Fisher EL. Hoarseness in Adults. Am Fam Physician 2017; 96(11): 720-8.

13. Majmudar $\mathrm{S}, \mathrm{Wu} \mathrm{J}$, Paganoni $\mathrm{S}$. Rehabilitation in amyotrophic lateral sclerosis: Why it matters. Muscle Nerve 2014; 50(1): 4-13

14. Hinchcliffe M, Smith A. Riluzole: real-world evidence supports significant extension of median survival times in patients with amyotrophic lateral sclerosis. Degener Neurol Neuromuscul Dis 2017; 7: 61-70.

15. Fang T, Al Khleifat A, Meurgey JH, Jones A, Leigh PN, Bensimon G, et al. Stage at which riluzole treatment prolongs survival in patients with amyotrophic lateral sclerosis: a retrospective analysis of data from a dose-ranging study. Lancet Neurol 2018; 17(5): 416-22.

16. Yunusova Y, Plowman EK, Green JR, Barnett C, Bede P. Clinical Measures of Bulbar Dysfunction in ALS. Front Neurol 2019; 10(FEB). 